Zeitschrift für Kristallographie, Bd. 136, S. 245-254 (1972)

\title{
The structure of the synthetic zeolite (K,Ba)-G,L
}

\section{By Ch. BAERLocher and R. M. BARRER}

Physical Chemistry Laboratories, Chemistry Department, Imperial College, London*

(Received 5 May 1972)

\begin{abstract}
Auszug
Die Kristallstruktur des synthetischen Zeolites (K, Ba) -G, $L$ bei Zimmertemperatur, mit einem Zellinhalt von $\mathrm{K}_{2.7} \mathrm{Ba}_{7.65}\left[\mathrm{Al}_{18} \mathrm{Si}_{18} \mathrm{O}_{72}\right] \cdot 23 \mathrm{H}_{2} \mathrm{O}$, wurde mittels genauer Pulverdaten bestimmt. Der Zeolith ist hexagonal mit den Gitterkonstanten $a=18,70 \AA$ und $c=7,50 \AA$. Die Stuktur wurde unter der Annahme der Raumgruppe $P 6 / \mathrm{mmm}$ bis zu einem $R(I)$-Wert von 0,13 verfeinert.

Das Alumosilikatgerüst von $(\mathrm{K}, \mathrm{Ba})-\mathrm{G}, L$ ist demjenigen von Zeolith $\mathrm{L}$ sehr ähnlich. Die beiden Zeolithe haben jedoch verschiedene chemische Zusammensetzung. Sie unterscheiden sich sowohl im Si/Al-Verhältnis als auch in den Kationen, welche die Ladung des Gerüstes neutralisieren. Es sind drei Kationenpositionen gefunden worden, wovon sich nur eine im Hauptkanal befindet. Nur die Ionen im Hauptkanal können leicht ausgetauscht werden.
\end{abstract}

\section{Abstract}

The crystal structure of the synthetic zeolite (K,Ba)-G,L, of unit cell composition $\mathrm{K}_{2.7} \mathrm{Ba}_{7.65}\left[\mathrm{Al}_{18} \mathrm{Si}_{18} \mathrm{O}_{72}\right] \cdot 23 \mathrm{H}_{2} \mathrm{O}$, has been determined at room temperature from accurate powder data. The zeolite is hexagonal with $a=18.70 \AA$ and $c=7.50 \AA$. The structure was refined to an $R(I)$ value of 0.13 assuming space group $P 6 / \mathrm{mmm}$.

The aluminosilicate framework of $(\mathrm{K}, \mathrm{Ba})-\mathrm{G}, L$ is very similar to that of zeolite L. However the chemical compositions of the two zeolites differ substantially, both in the $\mathrm{Si} / \mathrm{Al}$ ratios and in the ions which neutralize the framework charge. Three cation positions were located but only one of these is in the main channel. Ions in the main channel are the only ones likely to exchange readily.

\section{Introduction}

In 1964 Barrer and Marshall reported the synthesis of a synthetic Ba zeolite, called Ba-G, which had no natural counterpart. Barrer and MaInwaring (1972) repeated this synthesis using

\footnotetext{
* London SW7 2AY.
} 
metakaolinite with and without additional silica as starting materials, and also showed that the yield and purity of this species was increased when using a mixture of $\mathrm{K}$ and Ba hydroxides. They were able to index it on a hexagonal unit cell, similar to that of zeolite $L$ (BARRER and VILLIGER, 1969a) and zeolite $\Omega$ (BARRER and VILLIGER, 1969b). But they pointed out that the intensities of this new species resembled those of zeolite L.

Despite the low silica/alumina ratio the zeolite has a high thermal stability. It also shows promising sorption properties (MAINwaring, 1970). Therefore it was thought interesting to confirm the proposed framework structure by an x-ray structure determination and if possible to locate the cations. To avoid ambiguity the species has been renamed (K, Ba) $-\mathrm{G}, L$, where the letter $L$ indicates that it has a framework similar to that in zeolite $\mathrm{L}$.

\section{Experimental}

Chemical analysis of the sample used in this structure determination gave the following results:

$$
\left(0.15 \mathrm{~K}_{2} \mathrm{O}, 0.85 \mathrm{BaO}\right) \mathrm{Al}_{2} \mathrm{O}_{3} \cdot 2.14 \mathrm{SiO}_{2}, 2.6 \mathrm{H}_{2} \mathrm{O} \text {. }
$$

The measured density was $2.46 \mathrm{~g} / \mathrm{cm}^{3}$. The hexagonal cell dimensions were determined by means of a Guinier photograph with $\mathrm{Cu} K \alpha_{1}$ radiation and lead nitrate as an internal standard. The refined values are:

$$
a=18.701 \pm 0.002 \AA, c=7.501 \pm 0.001 \AA .
$$

The above results lead to an average unit cell content of

$$
\mathrm{K}_{2.7} \mathrm{Ba}_{7.65}\left[\mathrm{Al}_{18} \mathrm{Si}_{18} \mathrm{O}_{72}\right] \cdot 23 \mathrm{H}_{2} \mathrm{O} \text {. }
$$

The x-ray powder pattern was obtained with a Philips PW 1050/25 powder diffractometer using $\mathrm{Co} K \alpha$ radiation. A numerically controlled step-scan device, designed by M. T. Frost and D. Whitehead of the Geology Department was used, which punched the output on paper tape. With the aid of a computer program partially overlapping peaks were resolved. Thus 147 lines were measured up to $2 \theta=90^{\circ}, 121$ of which were clearly above background. For the least-squares refinement individual weights have been assigned to the intensities according to the counting rate and the degree of overlapping. No absorption correction was applied. For purpose of identification calculated spacings and relative intensities for $\mathrm{Cu} K \alpha$ radiation are given in Table 1. 


\begin{tabular}{|c|c|c|c|c|c|c|c|c|c|c|c|c|c|c|}
\hline h $k 1$ & ${ }^{d e a l c}$ & $x_{r e 1}$ & $h<1$ & deale & $I_{\text {rel }}$ & $h \mid k 1$ & deale & $\mathrm{I}_{\mathrm{rel}}$ & h $k 1$ & deale & $I_{r=1}$ & $b \quad k \quad 1$ & deale & ${ }_{1}$ rel \\
\hline 100 & 16.196 & 100 & 311 & 3.854 & 7 & 501 & 2.974 & 2 & 003 & 2.500 & $<1$ & 303 & 2.269 & - \\
\hline 110 & 9.350 & 4 & $\begin{array}{llll}0 & 0 & 2\end{array}$ & 3.750 & 2 & 222 & 2.926 , & 31 & 103 & 2.471, & 5 & 620 & 2.246 & $<1$ \\
\hline 200 & 8.098 & $<1$ & 320 & 3.716 & 2 & $5: 0$ & 2.909 & 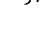 & 610 & $2.470^{\prime}$ & J & 441 & 2.232 & 14 \\
\hline 001 & 7.501 & 16 & 102 & 3.654 & 2 & 312 & 2.879 & & 502 & 2.451 & 8 & 701 & $2=2$ & \\
\hline 101 & 6.806 & 3 & $4 \begin{array}{lll}4 & 0 & 1\end{array}$ & 3.563 & $<1$ & 331 & 2.872 & 5 & 521 & $2.451^{\prime}$ & & 531 & & 3 \\
\hline 210 & 6.121 & 1 & 410 & 3.534 & 1 & 421 & 2.834 & 4 & 113 & 2.416 & $<1$ & 223 & 2.205 & 8 \\
\hline 111 & 5.851 & 1 & 112 & 3.481 & 10 & 402 & 2.752 & 2 & 332 & 2.397 & 3 & 602 & 2.199, & \\
\hline 201 & 5.503 & $<1$ & 202 & 3.403 & $<1$ & 511 & 2.712 & & 203 & 2.789 & - & 313 & $2.185^{\prime}$ & 3 \\
\hline 300 & 3.398 & 3 & 321 & 3.329 & 16 & 600 & 2.699 & $2 t$ & 422 & 2.371 & 1 & 432 & 2.171 & $<1$ \\
\hline 211 & 4.743 & 7 & 500 & 3.239 & 19 & 430 & 2.662 & 2 & 611 & 2.346 & 1 & 621 & 2.152 & - \\
\hline 220 & 4,675 & 3 & 212 & 3.198 & 10 & 322 & 2.639 & 10 & 440 & 2.338 & 4 & 710 & 2.145 & " \\
\hline 310 & 4.492 & $<1$ & 411 & 3.197 & 10 & 520 & 2.593 & 1 & 213 & 2.315 & & 522 & 2.135 & - \\
\hline 301 & 4.382 & 3 & 330 & 3.117 & 26 & 412 & 2.572 & - & 700 & 2.314 & 3 & 405 & 2.127 & 1 \\
\hline 400 & 4.049 & 1 & 302 & 3.080 & 26 & 601 & 2.540 & 2 & 530 & 2.314 & & 323 & 2.074 & \\
\hline 221 & 3.968 & 46 & 420 & 3.061 & 4 & 431 & 2.509 & 5 & 512 & 2.298 & 2 & 540 & $2.074^{\prime}$ & 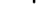 \\
\hline
\end{tabular}

The material investigated was synthesized using as starting material a metakaolinite which contained some anatase as impurity. Therefore the intensity of the lines $410,422,(513 / 810), 004,(404 / 703 /$ $533 / 910 / 650)$ and $(623 / 642)$ had to be corrected approximately for overlap with anatase lines.

For purposes of Fourier synthesis, values of $F_{\text {obs }}$ were assigned which were proportional to the calculated structure amplitudes (BROUSSARD and SHOEMAKER, 1960).

\section{Determination and refinement of the structure}

There are three framework structures or structure proposals which have approximately the cell dimensions of $(\mathrm{K}, \mathrm{Ba})-\mathrm{G}, L$ and which also explain qualitatively the observed sorption properties. These are the frameworks of zeolite L (BARRER and VILLIGER, 1969a), the second proposal considered by these authors for zeolite $\mathrm{L}$, and a third structure not considered at that time. In the present work this third structure was ruled out because the required extinctions were not observed.

For both the remaining proposals initial framework coordinates were calculated with the aid of the distances least-squares program DLS (MEIER and VILLIGER, 1969) using a mean (Si, $\mathrm{Al}$ )-O distance of $1.681 \AA$ corresponding with the observed $\mathrm{Si} / \mathrm{Al}$ ratio of 1 . However, right from the start the refinement of the second proposal did not progress very well and it was soon evident that the structure of (K, Ba)-G, $L$ must indeed be based on the L-type framework.

If one does not distinguish between $\mathrm{Si}$ and $\mathrm{Al}$ the highest possible symmetry for the L-type framework is $P 6 / \mathrm{mmm}$. This space group was used during the whole structure determination. The first threedimensional difference Fourier maps were based on the distance 
least-squares (DLS) framework coordinates and an overall temperature factor of 3.0 $\AA^{2}$. They showed two rather high peaks $\mathrm{Ba}$ (1) and $\mathrm{Ba}$ (2). The first one is located in the cancrinite cage and the second midway between two adjacent cancrinite cages. In addition a somewhat smaller peak, later called $(\mathrm{K}, \mathrm{Ba})$, was found in the main channel, in front of the eight-membered ring. Including $\mathrm{Ba}(1)$ and $\mathrm{Ba}(2)$ as fully occupied and $(\mathrm{K}, \mathrm{Ba})$ as half occupied $\mathrm{Ba}$ positions reduced the $R(I)$ value $^{1}$ from the relatively high initial value of 0.76 to 0.34 . From further three-dimensional $F_{\mathrm{o}}$ and $F_{\mathrm{c}}$ maps shifts were calculated for positional parameters of the framework atoms and the occupancy factors of the cation positions were adjusted.

For reasons discussed later the determination of water positions proved to be difficult. Nevertheless, two fairly distinet peaks, I and II, were located near the cation position $(\mathrm{K}, \mathrm{Ba})$. They were included using the scattering factor of oxygen. Further difference and $F_{0}$ maps showed a number of small additional peaks, most of them overlapping, nearer to the centre of the main channel. Instead of including all these positions with a low occupancy, it was decided to insert only the most relevant peaks and to allow their temperature factors to become rather high if necessary. This was thought to be justified since it helped to keep the number of parameters to a minimum without really limiting the information which it is possible to deduce from the available data. Thus only three further sites III, IV and V were included, the last of which disappeared during the course of the refinement. The least-squares refinement was then commenced with the aid of the ORFLS computer programme (BUSING, MARTIN and LEVY, 1967) adapted for powder data. The function minimized was:

$$
r=\sum_{j} w_{j}\left(Y_{\mathrm{o}}-Y_{\mathrm{c}}\right)_{j}{ }^{2} ; \quad Y_{\mathrm{c}}=\sum_{i} m_{i} L p_{i}\left(s F_{i}\right)^{2},
$$

where $w_{j}$ is the weighting factor and $L p_{i}$ is the Lorentz and polarisation factor. Since the cation position $(\mathrm{K}, \mathrm{Ba})$ had a comparatively low occupancy using the scattering factor of $\mathrm{Ba}^{2+}$, it was concluded that

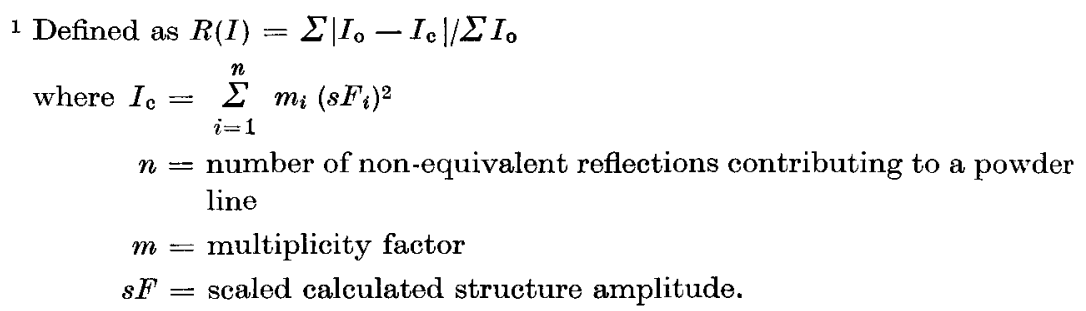


Table 2. Parameters of hydrated (K, Ba) $-\mathrm{G}, L$ (estimated standard deviations are given in brackets)

\begin{tabular}{|c|c|c|c|c|c|c|}
\hline Atom & $\begin{array}{l}\text { Position } \\
\text { based on } \\
P 6 / m m m\end{array}$ & $\begin{array}{c}\text { Fraction } \\
\text { occup. } 1\end{array}$ & $x$ & $y$ & $z$ & $B^{2}$ \\
\hline$(\mathrm{Si}, \mathrm{Al})(1)$ & $12 q$ & 1 & $0.0890(15)$ & $0.3500(15)$ & $1 / 2$ & $0.3 \AA^{2}$ \\
\hline$(\mathrm{Si}, \mathrm{Al})(2)$ & $24 r$ & 1 & $0.1665(15)$ & $0.4980(15)$ & $0.2175(15)$ & 0.6 \\
\hline $\mathrm{O}(1)$ & $6 k$ & 1 & 0 & $0.2675(35)$ & $1 / 2$ & 1.7 \\
\hline $\mathrm{O}(2)$ & $6 m$ & 1 & $0.1635(15)$ & 0.3270 & $1 / 2$ & 1.0 \\
\hline $\mathrm{O}(3)$ & $12 o$ & 1 & $0.2690(10)$ & 0.5380 & $0.2765(40)$ & 1.7 \\
\hline$O(4)$ & $24 r$ & 1 & $0.0980(15)$ & $0.4045(20)$ & $0.3225(30)$ & 2.2 \\
\hline$O(5)$ & 120 & 1 & $0.4315(15)$ & 0.8625 & $0.2545(50)$ & 7.0 \\
\hline $\mathrm{O}(6)$ & $12 p$ & 1 & $0.1540(25)$ & $0.4825(25)$ & 0 & 5.3 \\
\hline $\mathrm{Ba}(1)$ & $2 d$ & 1.0 & $1 / 3$ & $2 / 3$ & $1 / 2$ & 4.1 \\
\hline $\mathrm{Ba}(2)$ & $3 g$ & 0.83 & 0 & $1 / 2$ & $1 / 2$ & 6.2 \\
\hline $\mathrm{K}, \mathrm{Ba}^{3}$ & $6 j$ & 0.73 & 0 & $0.3250(10)$ & 0 & 5.1 \\
\hline I & $6 j$ & 0.85 & 0 & $0.1780(55)$ & 0 & 11.0 \\
\hline II & $6 l$ & 0.95 & $0.1450(25)$ & 0.2900 & 0 & 13.5 \\
\hline III & $12 n$ & 1.0 & 0 & $0.1455(30)$ & $0.3420(50)$ & 20.5 \\
\hline IV & $12 o$ & 0.40 & $0.1110(35)$ & 0.2220 & $0.2090(150)$ & 4.5 \\
\hline
\end{tabular}

1 Estimated standard deviation of the order of 0.02 and 0.1 for cations and sites $\mathrm{I}-\mathrm{IV}$ respectively.

${ }^{2}$ Estimated standard deviation of $0.5-1.0 \AA^{2}$ for framework atoms and cations and 3.0-4.0 $\AA^{2}$ for sites I...IV.

${ }^{3}$ Refined assuming a $\mathrm{K} / \mathrm{Ba}$ ratio of 1 .

Table 3. Interatomic distances (estimated standard deviations in brackets)

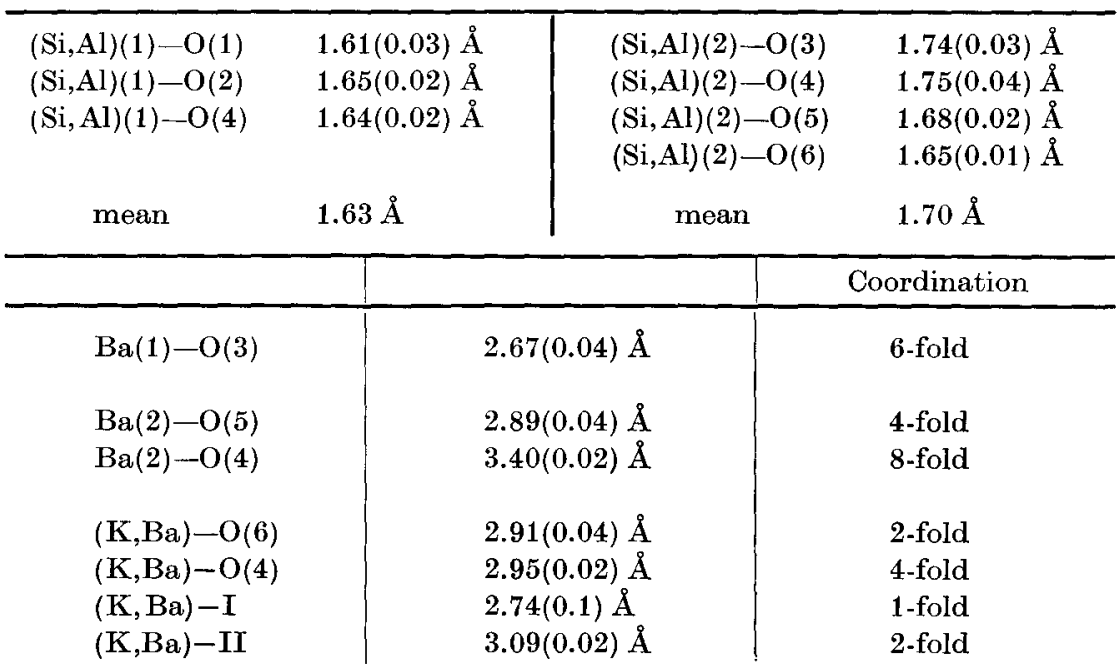


Table 4. Observed and calculated values of the corrected intensities of $(\mathrm{K}, \mathrm{Ba}) \cdot \mathrm{G}, L . I_{\mathrm{calc}}=\underset{i}{\sum} m_{i}\left(s F_{i}\right)^{2}$

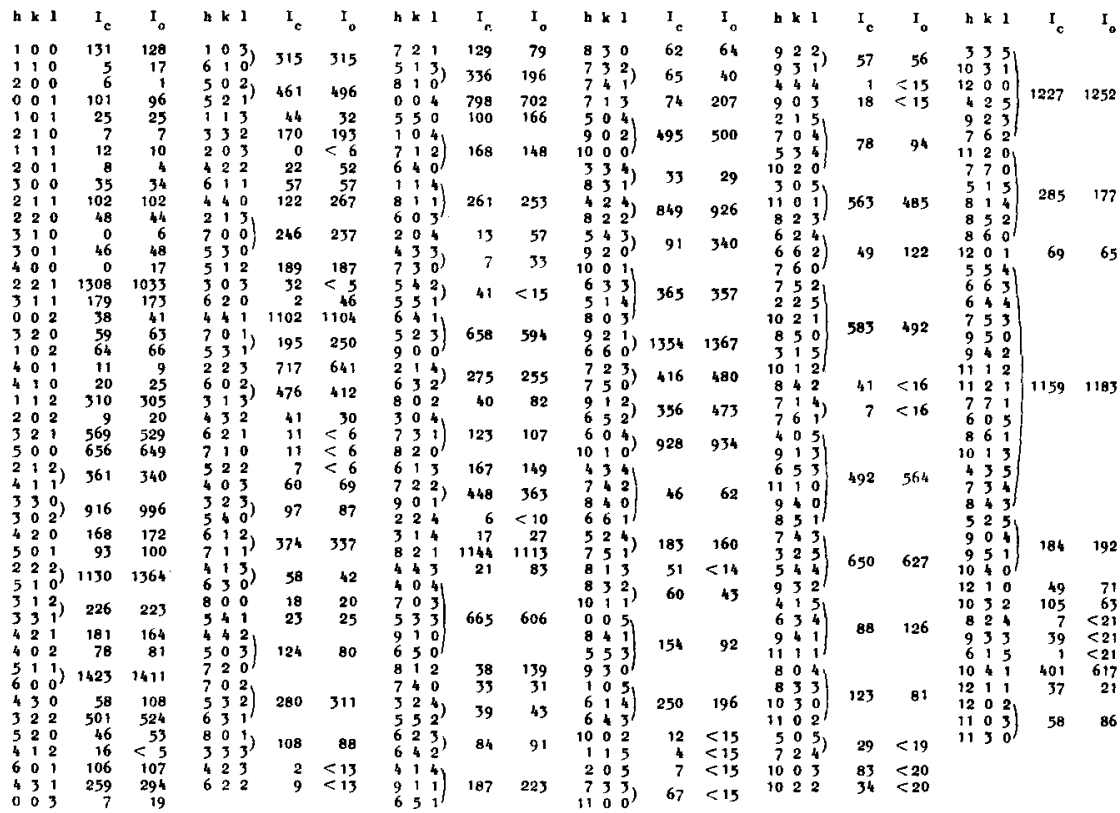

most of the $\mathrm{K}^{+}$must be accommodated in this position. During the final least-squares cycles a mixed scattering factor was therefore used, corresponding to a $\mathrm{K} / \mathrm{Ba}$ ratio of 1 . The refinement finally stopped at the $R(I)$ value of 0.13 for the observed reflections, which corresponds with a conventional $R(F)$ value of 0.10 . A final difference Fourier map showed no significant peak.

The final atom parameters with their estimated standard deviations are shown in Table 2. Those interatomic distances which are of interest are assembled in Table 3. Lastly, Table 4 contains the calculated and observed values for the corrected intensities.

\section{Results and discussion}

\section{Framework}

Although the L-type framework has been described in detail elsewhere (BARrer and Villiger, 1969a; Meier and Olson, 1971) a stereoscopic drawing is presented in Fig. 1. It shows clearly how the columns consisting of cancrinite cages joined by bridges of six oxygen atoms are linked to form the large main channel with its twelvemembered ring windows. Since the sample of (K, Ba)-G, $L$ examined 

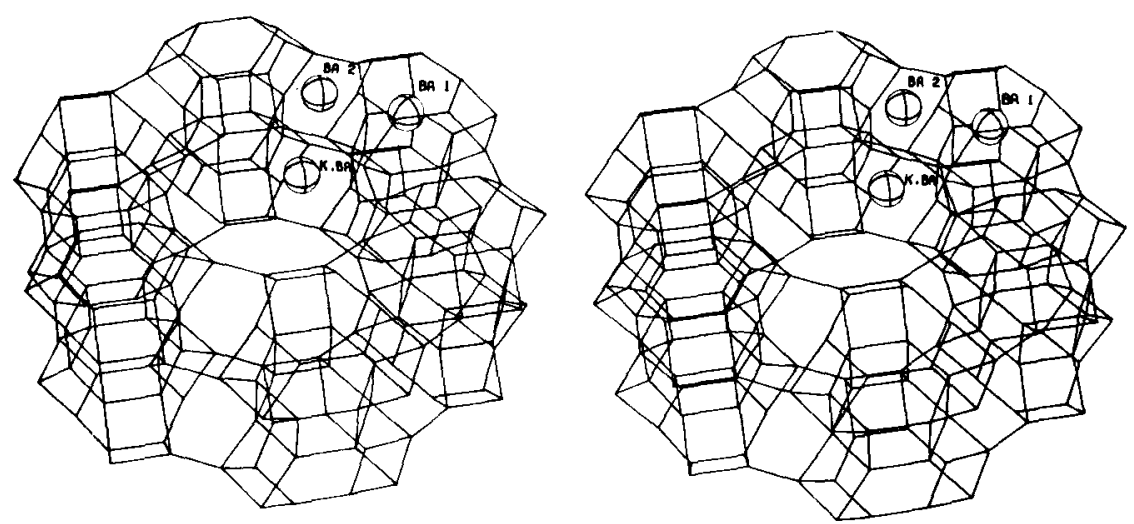

Fig. 1. Stereoscopic drawing of the framework structure of $(\mathrm{K}, \mathrm{Ba})-\mathrm{G}, L$. (Si, $\mathrm{Al})$ atoms are centred at the apices, oxygen atoms are not shown. Also indicated are the three cation sites

is more aluminous than zeolite $(\mathrm{Na}, \mathrm{K})-L$, its $a$ cell dimension is increased by $0.3 \AA$. Apart from this, no significant differences were found between the two framework structures. This was anticipated because the framework is fairly rigid.

The overall mean $(\mathrm{Si}, \mathrm{Al})-\mathrm{O}$ distance was found to be $1.67 \AA$. Within the limits of error, this is in agreement with the expected value of $1.681 \AA$ for a Si/Al ratio of 1 (RrbBe and GIBBS, 1969). However, the $(\mathrm{Si}, \mathrm{Al})-\mathrm{O}$ distances of the $(\mathrm{Si}, \mathrm{Al})(1)$ tetrahedra are significantly shorter and this might suggest a concentration of Si in the twelve-membered ring. This would be similar to the conclusion $\mathrm{G}_{\mathrm{ARD}}$ and TAIT (1972) drew in their discussion of the structure of offretite. Offretite possesses the same columns of cancrinite cages joined by six oxygen bridges as in zeolite L. But such a conclusion is not possible in the present case. According to Loewenstein's rule (1954) $\mathrm{Si}$ and $\mathrm{Al}$ have to alternate in a framework with a $\mathrm{Si} / \mathrm{Al}$ ratio of 1 . It is therefore most likely that these shortenings of the ( $\mathrm{Si} / \mathrm{Al})-\mathrm{O}$ distances are due to symmetry restrictions and averaging by the assumed high symmetry. The restrictions are more severe for the atoms in the twelve-membered ring than they are for the atoms in the hexagonal prisms.

\section{Cations}

Three different cation sites were located. They are shown in Fig.1. Position $\mathrm{Ba}(1)$ in the centre of the cancrinite cage is fully occupied by $\mathrm{Ba}^{2+}$ ions. On the other hand, position $\mathrm{Ba}(2)$, midway between the 
centres of two adjacent cancrinite cages was found to have only fractional occupancy. This could of course mean that some $\mathrm{K}^{+}$ions also occupy this position. However, most of the $2.7 \mathrm{~K}$ per unit cell indicated by the chemical analysis are thought to be located in the position $(\mathrm{K}, \mathrm{Ba})$, in front of the boat-shaped eight-membered ring. This is the only eation position that lies in the main channel and which is therefore exchangeable. It was refined assuming a $\mathrm{K} / \mathrm{Ba}$ ratio of 1 and a final fractional occupancy factor of 0.73 was obtained. On the above assumption this corresponds with $2.2 \mathrm{~K}^{+}$per unit cell.

All the three cation positions described have also been found in zeolite L. They account in terms of electrons for $87 \%$ of the cations found by chemical analysis. The remaining cations (corresponding approximately with one $\mathrm{Ba}^{2+}$ per unit cell) are probably distributed in the main channel. In contrast to zeolite (Na,K)-L (BARRER and VILLIGER, 1969a) and natural offretite (GARD and TAIT, 1971) no scattering matter was found in the hexagonal prism. The shortest distances between cations and framework oxygen atoms are listed in Table 3. They compare favourably with $\mathrm{Ba}-\mathrm{O}$ distances found in other Ba aluminosilicates such as celsian (Newnham and Megaw, 1960) and harmotome (SAdanaga, Marumo and TakéUCHI, 1961). In these structures the ranges of $\mathrm{Ba}-\mathrm{O}$ distances are $2.67 \AA-3.14 \AA$ and $2.77 \AA-3.26 \AA$ respectively.

\section{Zeolitic water}

As mentioned earlier, the determination of meaningful water positions was not possible. The main reasons for this are as follows. It appears that the larger the cavities and channels of zeolites, the less fixed are the water molecules at particular positions. The water becomes more fluid-like the further away it is from the framework. Accordingly, GramLich (1971), for example, found it very difficult to locate and refine meaningful water positions in the main channel of natural mordenite. At the same time, it is likely that the arrangement of the water molecules does not possess the high symmetry assumed for the refinement of the framework. This would also result in smearing out some positions. In addition, the partial occupancy of position $(\mathrm{K}, \mathrm{Ba})$ suggests that the arrangement of the water positions may vary depending on the presence or absence of a cation. For these reasons the refined water positions, especially the sites III and IV, cannot be taken as accurately representing the locations of fixed water molecules. To give some idea, however, of the water distribution 

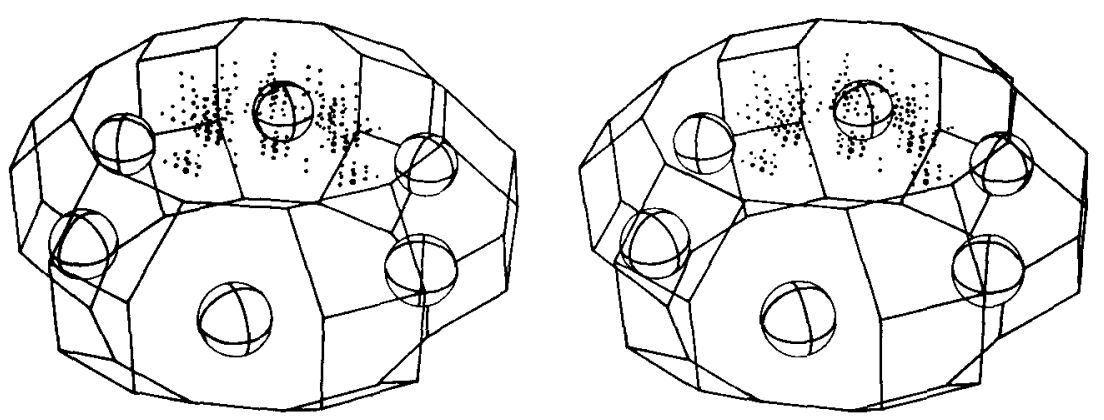

Fig. 2. Electron distribution in the main channel. The radii of the black circles are proportional to the electron density. The cation position $(\mathrm{K}, \mathrm{Ba})$ is also shown

a stereoscopic drawing of the electron density in the main channel is given in Fig. 2. The $F_{0}$ map for this figures was calculated using the final coordinates.

\section{Si,Al distribution}

It has been noted earlier that the true symmetry of $(\mathrm{K}, \mathrm{Ba})-\mathrm{G}, L$ must be lower than $P 6 / \mathrm{mmm}$. The ratio between the number of observations and the number of variables was 2.8 ( 3.3 when including unobserved reflections) which would only just allow a symmetry reduction of the order of 2 . On the other hand an ordered $\mathrm{Si} / \mathrm{Al}$ distribution would not only require a reduction in symmetry but also a doubling of the $c$ cell constant. However no evidence was found in the powder pattern for a doubled unit cell.

It is interesting to note, that while $(\mathrm{Na}, \mathrm{K})-\mathrm{L}$ crystallizes with a $\mathrm{Si} / \mathrm{Al}$ ratio of $2.5-3.5$ (BRECK and FLANIGEN, 1967), (K, Ba)-G, $L$ can evidently form with a ratio of 1 . This behaviour can perhaps be explained by the total number of cation sites available. These are the three positions already discussed totalling 11 per unit cell plus a possible position in the centres of the hexagonal prisms which adds two more. Therefore in an L-type structure having 36 (Si, $\mathrm{Al}$ ) tetrahedra per unit cell and containing only monovalent cations (e.g. Na, K) the minimum $\mathrm{Si} / \mathrm{Al}$ ratio would be 1.8 . Since it is often found that cation positions in zeolites are only partially occupied it is expected, and observed, that the ratio $\mathrm{Si} / \mathrm{Al}$ can exceed 1.8. On the other hand when divalent ions (e.g. $\mathrm{Ba}$ ) are present as in $(\mathrm{K}, \mathrm{Ba})-\mathrm{G}, L$, although no hexagonal prism sites were occupied, the remaining 11 positions per unit cell easily allow for $\mathrm{Si} / \mathrm{Al}$ ratios from 1 upwards. 


\section{Acknowledgments}

Thanks are due to Dr. D. E. MaInwaring for supplying the sample of (K. Ba)-G,L and the analytical data, and to Mr. M.T. FrosT of the Geology Department of Imperial College for making their $\mathrm{x}$-ray equipment available for the intensity measurements. One of us (Ch.B) is indebted to the Volkart Foundation, Winterthur, Switzerland, for a grant, and to Imperial College for subsequent support, which enabled him to take part in this work.

\section{References}

R. M. Barrer and D. E. Mainwaring (1972), Chemistry of soil minerals, Part XII. Transformations of metakaolinite with solutions containing barium hydroxide. J. Chem. Soc. Dalton 1972, 1259-1265.

R. M. Barrer and D. J. Marshall (1964), Hydrothermal chemistry of silicates. Part XIII. Synthetic barium aluminosilicates. J. Chem. Soc. [London] 1964, $2296-2305$.

R. M. Barrer and H. Villiger $(1969 a)$, The crystal structure of synthetic zeolite L. Z. Kristallogr. 128, 352-370.

R. M. Barrer and H. Villiger (1969 b), Probable structure of zeolite $\Omega$. Chem. Comm. 659-660.

D. W. Breck and E. M. Flanigen (1967), Synthesis and properties of Union Carbide zeolites L, $\mathbf{X}$ and $\mathbf{Y}$. Conference on Molecular Sieves, Society of Chemical Industry, London, 47--60.

L. Broussard and P. D. Shoemaker (1960), The structure of synthetic molecular sieves. J. Amer. Chem. Soc. 82, 1041-1051.

W. R. Busing, K. O. Martin and H. A. Levy (1967), ORFLS, a crystallographic least-squares program.

J. A. GARD and J. M. TATT (1972), The crystal structure of the zeolite offretite. Acta Crystallogr. B 28, 825-834.

V. GraMLICH (1971), Untersuchung und Verfeinerung pseudosymmetrischer Strukturen. Ph. D. Thesis, Nr. 4633, ETH, Zürich.

W. LOEWENSTEIN (1954), The distribution of aluminum in the tetrahedra of silicates and aluminates. Amer. Min. 39, 92-96.

D. E. Mainwaring (1970), Hydrothermal zeolite crystallization from clay minerals. Ph. D. Thesis, Imperial College, London.

W. M. Meier and D. H. Olson (1971), Zeolite frameworks. Adv. Chem. Ser. $101,155-170$.

W. M. Meier and H. Villiger (1969), Die Methode der Abstandsverfeinerung zur Bestimmung der Atomkoordinaten idealisierter Gerüststrukturen. Z. Kristallogr. 129, 411-423.

R. E. Newnham and H.D. Megaw (1960), The crystal structure of celsian (barium felspar). Acta Crystallogr. 13, 303-312.

P. H. RIBBe and G. V. GIBBS (1969), Statistical analysis and discussion of mean $\mathrm{Al} / \mathrm{Si}-\mathrm{O}$ bond distances and the aluminum content of tetrahedra in feldspars. Amer. Min. 54, 85-94.

R. Sadanaga, F. Marumo and Y. Takéuchi (1961), The crystal structure of harmotome. Acta Crystallogr. 14, 1153-1163. 